\title{
Transition and the Problems of Modern Nigerian Poetry: An Overview of Selected Nigerian Northern and Southern Poets
}

\author{
Mbanefo S. Ogene \\ *http://dx.doi.org// 0.43 I4/ujah.v17i3.4
}

\section{Abstract}

Ever since Aristotle propounded the theory of the difference between literature and history, scholars and researchers have continued to develop different levels of interests on the problems bothering on these two fields of study. Even though Aristotle expressed the view that "history reports the particular truth while literature reports the universal', literary theorists have over time absorbed history into literature, while critics have equally adopted it as a critical approach. The controversy surrounding literature and history is such that other terms like transition, movement, periodization and regionalization have come to share in the broad scope of this idea. This paper attempts a scrutiny into the position of history and transition in literature and the problems these have posed in the study of modern Nigerian poetry. It uses the works of some Northern and Southern Nigerian poets to make an incursion into these areas and observes that history has indeed played $a$ part in the modern Nigerian poetry.

\section{Introduction}

Origin/Concept of Transition in Nigerian Literature

A modern African culture, whatever else it might be, must be a continuation of old African culture. Whatever else it includes, it must include seminal and controlling elements from the African tradition, elements, which determine its tone, hold it together, and give it a stamp of distinctness. 
The word transition has many definitions, but the essential ones considered for this paper are those given by: the Webster's New International Dictionary of the English Language, which says that 'in a historical development' transition stands for

evolution or the like, a passage from one clearly defined stage, type, or style, to another; a changing from an earlier to a later form with the change, as the language is in a state of transition; to undergo transition; during the transition in government; (Websters: 269I).

The $B B C$ English Dictionary defines transition as "a change from one form or state to another" (BBC: 1246)

The word transition has gained so much popularity in the Nigerian socio-political scene that the Federal Government of Nigeria in 1985, under the military administration of General Ibrahim Badamasi Babangida, introduced it in the programme of government of the nation. Its objective was to see to the formal hand over of the military rule to civil democratic government, starting from $27^{\text {th }}$ August 1985 (when Babangida took over government) to 1992 (intended for his hand over). Etymologically, transition means "passage from one condition or action to another" (Onions: 937).

History has to do with the notable occurrences of events that follow serially within the existence of a given people, community or nation. In the study of transition, historical events need be considered as essential parts of the programme. It is also necessary to note that history has no limitation either by space or time and therefore needs be studied from a particular point in time. 
In the historical study of Nigeria, there have been chains of transition in the government of the country. These periodic changes are necessitated by the colonial expedition cum imposition of alien system of government and culture on Nigerians. These contacts affected the oral literature of Nigerians with the consequent result that written records and literatures, developed sporadically in the Nigerian scenario. A notable scholar of oral tradition, Jan Vansina aptly noted this in his chapter on "Oral Tradition and Historical Methodology" when he stated that:

It may be said that the first historical writings based on oral tradition all date from the time when the first European explorers arrived upon the scene, and very nearly all that we know today about the early history of these pre-literate peoples is due to such amateur historians (Vansina: 7).

\section{Key Words}

In the course of this study, the key words; Regionalisation, Periodization and Movements in Nigerian poetry will often reflect interchangeably with transition.

Periodization is aptly attributed to mean the national experiences, history or time. In the British history there is the Classical Period, Renaissance period, Elizabethan and Victorian periods, among others. Periodization is also notable with leaders that were in power during a given study and equally extends to social, evangelical cum religious experiences.

Movement is used in this sense to identify separate units of norms in literature observed at a given point in time. 
Examples of movements are, Negritude, modernist and apartheid.

Regionalization can be used to delineate the different geographical mappings, units, boundaries groups and boarders, like in Nigeria where there are the Northern, Eastern and Western regions and other minor ethnic groups. Due to the problems encountered by the colonial masters, Nigeria was largely regionalized into the southern and northern regions.

Nigeria is a geographical entity in the continent of Africa with a federation that contains states and a federal capital territory. The country is characteristically defined as "one indivisible and indissoluble Sovereign state to be known by name of the Federal Republic of Nigeria" (Constitution: I)

\section{Antecedents to Nigerian Poetry The English poetry}

Nigeria as a sovereign nation colonized by Britain shares a lot of her literature traditions with Britain. As the English literature started from the old English period, so did the Nigerian literature start from the legendary period known largely as the pre-colonial period. There are also periods like the Renaissance, Elizabethan, Romantic, Victorian and Modern, in English poetry, from which the Nigerian poetry inherited some of its modern design and form. As the English literature recorded wars and conquests from German, French and Roman Empires, so did the Nigerian poetry record Jihad, slavery and foreign trade. The oral tradition, which gave birth to the English poems like "Beowulf, Sir Gawain and the Green Knight, Deor's Lament and the Wanderer" also, shares common equivalence with the Nigerian's folk tale and oral heritage. In the words of Emenyonu, "National literatures are founded on the oral 
heritage of their peoples. They are sustained on the pillars of works in the indigenous languages". (viii)

\section{Religion Influences on Nigerian Poetry}

Religious festivals, rites and worship contributed immensely to the shaping of both English and Nigerian poetry. This is as a result of man's search for the meaning of life. In Nigeria, three main religions, namely; the African traditional, Christian and Moslem religions are predominant and their doctrines reflected in Nigerian poetry. Writing on the "Historical Background to Medieval Literature", the authors noted that

The written records we possess from that time amount only to a handful of inscription, serving a no longer definable magical function, expressed in pagan characters known as runes. Runes continue to appear on Christian monuments, such as the Ruthwell Cross... on which a portion of the poem 'The Dream of the Rood', is carved... (Kermode and Hollander: 8)

This runes character is very akin to the "mobius strip" which was aptly described in Wole Soyinka's Idanre as a "mathemagical ring, infinite in self-recreation into independent but linked rings and therefore the freest conceivable (to me) symbol of human divine (e.g. Yoruba, Olympian) relationships ..." (Soyinka: 87)

\section{Politics}

As the Angles, Saxons and Jutes greatly contributed to the shaping of the English poetry, so did the Igbo, Yoruba and Hausa of Nigeria play major roles in the shaping of the history of the Nigerian poetry. Politics contributed to a large 
extent in the shaping of Nigerian poetry that it has reached the level of propaganda and commitment, which it harbours in the present times.

\section{Between the Modern and Modernism in Nigerian Poetry}

From various antecedents given, modernism involves opinions that are newly fashioned, deviation from the societal norms, change from the established tradition to new reasoning and an update in literature, of human condition, style and manner of living. Two basic issues that stand out in the definition of modernism are "old" and "new".

The controversy surrounding the term "modern" is on if there is anything that distinguishes it from the old, and if there is, from what point does one establish the modern from the old? Is modernism synonymous with realism or idealism? These questions have so much bothered the philosophers, historians, literary scholars and theologians that, while discussing on "The Modern World of Leo Strauss," Pippin states that:

The least controversial claim one could make is that his modernity critique is everywhere motivated by one great opposition, or gigantomachia, the quarrel between the ancients and the moderns. The best-known implications of Strauss's understanding of such a fundamental clash, and the origin of by far the greatest scholarly controversy, is his claim about ancient and much of early modern writing. It is esoteric. (Pippin: 212)

Studies have shown that most Nigerian poets seriously started embarking on publishing their works from the 1930s. Taking into consideration the period within 1930 and the present period, one may find it difficult to draw a border-line 
between the ancient poetry and the modern ones. Nwoga states however that, "the change to the 'modern' was a result of developments in two areas: in techniques of poetic expression and the sources of the poetic material" (Nwoga: 142).

While the early Nigerian poets are more concerned with the politics of the black man, problem of identity, roles of the poet in his society, misrule, independence of his country, colour identity and education of their people, the modern Nigerian poets are more interested in private symbolism, trial of new styles, form and language in poetry, so as to get new meaning.

Like Edward Estlin Cummings, Ezra Pound, T. S. Eliot and Gerard Manley Hopkins, who started new styles of writing, intended for the new American and European audience, the modern Nigeria poets started experimenting with the local images, themes, language and style. They forsook the European setting to the African setting; the gods, masquerades, rituals, sacrifices and other traditions, served as their creative tools.

The modern poets preferred the indigenous Nigerian name of a person, places and things to those of the Western Europe and they effectively exploited their cultural backgrounds to make their works real. There was a serious revolution in diction, style and theme of the modern Nigerian poets. According to Nwoga:

Our modern poets, under the influence of modern English poets, write poetry of greater complexity than those of the pioneers. They exhibit a greater freedom with syntax, word meanings and symbolism. There is less regularity in line lengths and fewer rhymes. And their poetry is less easy to understand, in general, of a 
higher imaginative intensity than that of the pioneers (I43).

While some scholars have identified the modern Nigerian poetry with politics, others have taken a more general approach to the topic. For Umeh, "Politics has constituted a major influence on modern Nigerian poetry" (Umeh: 46). In the study of the modern Nigerian poetry and Nigerian politics, there is the need to split the exercise into the three periods of: pre-independence, independence and postindependence poetry.

Since the pre-independence Nigerian poetry is related to the Nigerian colonial experience, the area of attention is on the post-independence Nigerian poetry. Due to the developmental trend in Nigeria, it is the view of this paper that there exists the early modern Nigerian poetry and the later modern Nigerian poetry. As earlier stated, the classification of poetry in Nigeria is not only based on historical data, but on both period and movement. Although Wole Soyinka's Idanre and Other Poems and A Shuttle in the Crypt were published respectively in 1967 and 1972 by Methuen London, they belong to different periods and movements, as Idanre was published at the onset of the Nigerian civil war, while A Shuttle in the Crypt was published during the post war period.

Examining what constitutes the modern Nigeria poetry, Chinweizu and others posit that "the severance of modern Nigerian poetry from what should be its oral African roots manifests itself most glaringly in matters of religion" (Chinweizu, Onwuchekwa and Ihechukwu: 187). To this school of thought, the European religion is inseparable with their modern design and cannot easily fit into the African standard. Be that as it may, some Nigerian poets, including Wole Soyinka and J.P. Clark-Bekederomo have proved this 
point wrong. It is on this note that some poets of modern Nigeria are approached. In the analysis of the modern Nigerian poetry, emphasis is on its relationship with the preceding period. The issues of theme, style, subject matter, language, form and other poetic devices, are examined.

\section{Modern Hausa poetry}

"Gargadi don Falkawa" or "A warning to be wakeful" is an Hausa poem, written by Na'ibi Sulaiman Wali of Kurawa quarter (Furniss: 216). This poem like most other modern Hausa poetry is both moralistic and didactic. These qualities are best observed in the language of the poem, which uses the religious terms to condemn and criticize the evils of the society:

You have rejected advice and turned away,

The devil has set you wrong.

And these women are prostitutes,

They reject God and embrace all that is bad.

When a woman becomes a prostitute,

She is pitifully ruined. She is no longer a woman Is this the way for us, my friends,

All our actions set at nought?

Will this part bring us

Directly to happiness?

In God's name, we here in Nigeria,

What can we do and what can we say?

We must be self-critical and pursue the truth,

Follow the true path without straying (219).

Unlike the early jihad poetry, this poem uses a softer, soothing and more polite language to admonish the Moslem faithful to continue being 'wakeful'. It is quite obvious that the problem of religion has always been a major part of the problems encountered in the Islamic places as they often 
speak Arabic due to their Islamic background. In his comment, Furniss states that:

the language of much modern Hausa poetry is reminiscent of the Victorian tract or the revivalist preacher. The power of this aspect of Hausa culture lies in its very directness and its ability to take any aspect of the social, political and cultural world of modern Nigeria and construct a characterization of that feature, be it person, event, or idea, in which certain aspects can be unequivocally condemned and other aspects clearly endorsed. (2।4-2।5)

Unlike the other Hausa poems, there is an innovation in the way this poem is concluded. The poet raises the optional issue of informing the malam, of the writer of the poem and his address, if anybody should ask question on the issue:

If they ask you who wrote

This poem, then, malam, tell them

His name is Na'ibi Wali,

And he lives in Kurawa quarter. (Furniss: 219).

The transition in the poetry from 'savagery' to 'civilization' is not unusual as every religious motif is to lead the adherents to peace, love, unity and progress. It is in consonance with the stages of national development.

Another poem by Salihu, written against oppression also uses prayer to condemn oppression:

Oppression is a disease,

So serious has it become that we are in crisis

The crime, which leads its perpetrator

Straight to hell-fire is oppression

(Salihu Quoted in Furniss: 22I). 
The poem decries the evils of bribery and its consequence, which is "confinement in the fires". It also leads to crime, extortion and other evils, which is oppression. The evils of oppression have been seriously condemned by the noted poet and winner of the Nobel Prize for literature, Wole Soyinka in his book, The Man Died when he aptly states that, "the man dies in all who keep silent in the face of tyranny." (Soyinka: 13). The "poem against oppression" goes into the survey of the Nigerian civil service, pointing out that there is reward for the virtuous man who works correctly, the honest policeman who pursues his duties to prevent crime and the honest judge. It further cites the Holy Koran which forbids oppressive acts in its two hundred and sixty first verses.

The modern Hausa poetry also uses criticism to pass its message across when Abdulkadir's verse states the uselessness of freedom; where poverty thrives, hopelessness of trust, with envy in people's hearts, worthlessness of leadership, without honesty, uselessness of human relationship, without generosity and other vices.

Imagery is applied when Abdulkadir criticizes further the political quagmire in the Northern Nigeria, before the Nigerian attainment of independence on the $I^{\text {st }}$ of October, 1960. The image of the North is "full" of dissension and wickedness, prostitution, towns filled with men of straw, homosexuals, swindlers, drunkards, beggars and to the poet, the Southern Nigerians will continue to rule the North as long as those evils thrive.

\section{Southern Region: the Poetry of John Pepper Clark- Bekederemo and Others}

Born in 1935 as John Pepper Clark-Bekederemo in Kiagbodo town of Delta State, Nigeria, by an ljo ethnic father and Urhobo ethnic mother, John Pepper Clark is a renowned and 
outstanding African writer. Clark, as he is popularly known, is distinguished as journalist, critic, playwright and poet, and was Professor of English at the University of Lagos. His published works include: A Decade of Tongues, Selected Poems 19581968; A Reed in the Tide (Poetry);Casualties (Poetry); State of the Union (Poetry) and Mandela and other poems. His plays are: Three plays (Song of a Goat, The Masquerade and The Raft); Ozidi; The Bikoroa Plays (The Boat, The Return Home, and Full Circle). His critical essays were published under the title, The Example of Shakespare.

John Pepper Clark -Bekederemo is considered as a modern Nigerian poet due to his dissent to pioneer Nigerian poets. While Okigbo, Osadebay, Okara and Soyinka made use of foreign images in most of their poems' added to their imitation of the western poets, Clark initiated the use of local image, language, character, style, subject matter and other forms of poetic techniques. Notwithstanding his uniqueness as modern Nigerian writer, Clark still borrowed his poetic devices from the early poets, as his medium of expression is English, although it is interwoven with his local ljo language. Consider his poem Abiku:

Coming and going these several seasons,

Do stay out on the baobab tree,

Follow where you please your kindred spirits

If indoors is not enough for you.

True, it leaks through the thatch

When floods brim the banks,

And the bats and the owls

Often tear in at night through the eaves,

And at harmattan, the bamboo walls

Are ready tinder for the fire

That dries the fresh fish up on the rack.

Still, it's been the healthy stock

To several fingers, to many more will be 
Who reach to the sun.

No longer then bestride the threshold

But step in and stay

For good. We know the knife scars

Serrating down your ears, notched

As a bondsman to this house,

Are all relics of your first comings.

Then step in, step in and stay,

For her body is tired,

Tired, her milk going sour

Where many more mouths gladden the heart

(Clark quoted in Nwoga: 3).

Apart from its ljaw background, critics have wondered whether Clark borrowed his poem from Wole Soyinka's Abiku', or if the later did the opposite. Whatever may be the case, the two poems have cultural relativity as they carry the mind of Nigerians. Abiku is a name of reincarnate child who comes and goes in cycles. In Igbo language, the term is known as "Ogbanje", while the ljaw and the Yoruba call it 'Abiku'. It is noteworthy that while Clark makes every effort to restrain himself within the Nigerian context of images, Soyinka makes use of such foreign images as "bangles", "lamps" and "doorstep".

The point is that modern Nigerian poetry is a continuation of the old Nigerian poetry and is therefore related to the past. In fact this is in consonance with the theory propounded by T.S. Eliot, who is one of the champions of modernist views in literature. In his terms:

No poet, no artist of any art, has his complete meaning alone. His significance, his appreciation is the appreciation of his relation 
to the dead poets and artists. You cannot value him alone; you must set him for contrast and comparison, among the dead (Eliot: 2014).

Due to the socio-political factor in the Nigerian poetic scenario, most of the poets are not dead, but living. The issue to consider therefore is that of "techniques of poetic expression and the sources of the poetic material" (Nwoga: 142). Like other poems of Clark's "Abiku" makes use of such local images like "baobab tree, thatch, floods, bats, owls, harmattan, bamboo walls and threshold". The theme of this poem is the controversial issue of reincarnation. While the western doctrine of reincarnation holds that souls can be born again in different bodies, the Nigerian religious belief is of the view that the "Abiku" repeats his life's cyclical journey in the same body. No wonder, the poet Clark mentions that;

... We know the knife scars

Serrating down your ears, notched

As a bondsman to this house,

(Are) all relics of your first comings.

The 'scars' are marks given to the Abiku on its second or preceding periods of existence. These marks are meant to confirm that the child is the same old stock and possibly, to make the child stay permanently in the family.

In another poem, "Olokun", Clark paints the picture of a mock-heroic goddess of the river, who through her rich bounties for men, enslave them. The poem is a lyric as its language touches on personification, metaphor and simile. In line 13 of the poem, Clark mentions "the touch of sleep" (Nwoga: 53), which is personification of sleep, as sleep is made to have hands with which to touch. There is also the 
use of metaphor in "the sable vehicle of dream" and simile in "so drunken, like ancient walls". The imagery of the sea waves is drawn as "the strands of your hair" (Line 4). On the whole, the lyrical nature of the poem is capped in its emotional expression.

In "Night Rain" Clark gives the picture of the peasant African, suffering under the merciless hands of the rainy season. He uses standard images and sounds to portray the picture of man's battle against fate. Notice the alliteration in "Doped out of the Deep" and "bobbed up belly wise" (Lines 4 and 5, in Nwoga: 59). Like Cummings, Clark's "Ibadan" is a short poem with beautiful images of a city scattered on seven hills. The comparison of Ibadan with the "broken china in the sun"(Nwoga: 57 ) is also very remarkable. The style of the poem is patterned after modernism, as it uses words to design a city.

Apart from his traditional poems, Clark also wrote political poems, which he published under the collections, sub-titled "From A Reed in the Tide" and "Casualties" (Clark: 34-|0I). Most of the poems in this sub-title are written in memory of the civil war period in the Nigerian societal history. "The Casualties (84)" and "Epilogue to Casualties" (88), are good examples of the poems commemorating the after effects of the Nigerian/Biafran civil war. "The Casualties" is a poem that discusses the theme of war casualties. From the poet's point of view; the dead, the wounded, the bereaved, prisoners of war, engineers of war, etc are not only the casualties, but the emissaries of rift, and in fact everybody in Nigeria, is a casualty of the civil war as:

... we cannot hear each other speak,

Because eyes have ceased to see the face from the crowd,

Because whether we know or 
Do not know the extent of wrong on all sides, We are characters now other than before The war began... (Clark: 85).

Clark's poetry gave rise to poets like Osundare, Akomaye Oko, Okey Umeh and Benji Egede, among other later poets of Nigeria. It is this challenge to remedy the wrongs done in the Nigerian historical past that led to such poem as "Nigeria We Hail Thee". In the language of the poem, which was written on Nigeria's $26^{\text {th }}$ Independence Anniversary, October I, 1986, the poet states thus:

Nigeria,

We hail thee;

Our father land dear,

We hail thee.

For thy fallen fences

Eaten by termites

And thy lifeblood

Sucked dry:

Nigeria we hail thee...

\section{(Umeh: 20).}

Patterned after the old Nigerian national anthem, this poem uses the title in the old national anthem (i.e. Nigeria, we hail thee) to satirize the country's shortcomings. In the poem, there are the theorists, cowards, embezzlers of money and corrupt officials in the Nigeria's political scene. The poet also condemns the post-independent Nigerian scene as poverty thrives. Starvation, fear of disintegration, false and feigned freedom from colonialists, "insidious dichotomy and tottering economy", still face Nigeria after forty - two years of nationhood. There is frustration, fluctuations, state of insecurity and uncertainty in the Nigerian nation, as the country lives in promises, dreams, illusions and delusions. 
Apart from using the oral method of the East African song tradition to write his poetry, Osundare introduced a new form of writing in the Nigerian poetry which embraces surrealism, neonames, geography and other modernistic features.

The Eye of the Earth, although a collection of poems, uses the geographic and agronomic features in Nigeria to satirize the political leaders who have lost human sympathy and vision, by implementing policies, targetted at exploitation of the masses. The poet aptly portrays the scene through the use of local images, which constitute the democratic spaces:

Here

there

everywhere

a lake is killed by the arsenic urine from the bladder of profit factories

a poisoned stream staggers down the hills coughing chaos in the sickly sea the wailing whale, belly up like a frying fish crests the chilling swansong of parting waters.

But our earth will not die.

(Osundare: 50$)$.

In Songs of the Market Place, Osundare uses poetry definition as a subject matter of his poem entitled "Poetry Is". Apart from its use of simple language and form, the poem offers a thematic definition cum theory of poetry from an African poet's perspective. Osundare's use of verse style to present his theme of poetry definition is very unique and noteworthy. He succeeds in demystifying poetry, which has been held in some quarters to mean "esoteric whisper, of an excluding tongue, claptrap for a wondering audience and learned quiz enthroned in Greco-Roman lore.” For the poet, 
Poetry is

a lifespring

which gathers timbre

the more throats it plucks

harbinger of action

the more minds it stirs...(Osundare : 4)

It is in an effort to negotiate the democratic spaces of Nigeria that Osundare uses his local Yoruba language in most of his poems. Terms like: "tanwiji (i.e. mosquito larvae), molue, danfo, dagbere (i.e. names of passenger vehicles), omolanke (i.e. hand pushed cart), ekan (i.e. elephant grass) and agbero (tout), are effectively used in Songs of the_Market Place, while terms like: efurudowo (standing for efuru, i.e. Ekiti's most important yam), esuru (another type of yam, hard to pound), and kolatera (which is an adaptation of the English word collateral) are used in Village Voices (Osundare : 42, 48 and 50)."

Waiting Laughters which was published in 1990, alongside Songs of the Season by Niyi Osundare is perhaps the modernist oriented collection of the Nigeria born poet. The epic is meant to be performed with the local Yoruba Musical instruments of flute, kora, goje, gangan, bata, ibembe and sekere.

In Waiting Laughters, there is timeless waiting in the Nigerian socio-political scene that makes waiting itself become paradoxical. The act of waiting reaches such a climax of absurdity that the reader of the poem cannot help but laugh at and fall for. It is excursionist and catechetical in nature. Images of different waiting scenes abound in the poem, factors that contribute to the over complexity of some parts and over simplification of the other parts. There is high-flown symbolism and political undertones, which the poet projects through the use of lyricism and cynicism. 
Waiting Laughters highly exploited Cumming's style of modernist writing, that it makes use of new word forms like:

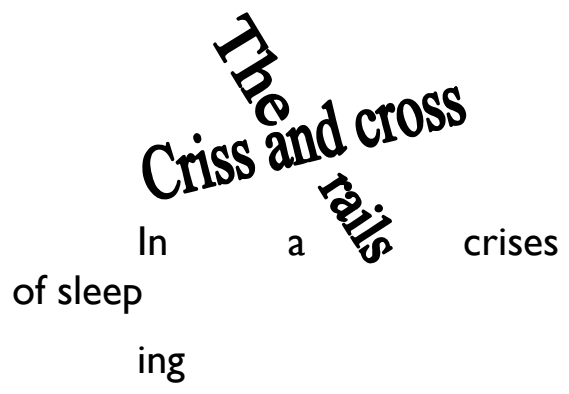

steel

(32)

and new names like, breaking of words to form sentences and breaking of alphabets to form words, as in:

Long-
er
than
the
$y$
a
$\mathrm{w}$
$\mathrm{n}$
of
the
moon...

On the whole, there is the theme of disenchantment, turbulence and moral decadence, which is marked in the post-colonial Nigeria poetry.

Mbanefo S. Ogene

Department of English Language and Literature 
Nnamdi Azikiwe University, Awka, Nigeria

\section{Works cited}

BBC English Dictionary. London: Harper Collins Publishers, 1992.

Chinweizu. The West and the Rest of Us. Lagos: Nok, 1978

Chinweizu, Onwuchekwa Jemie and Ihechukwu Madubuike. Toward the Decolonization

of African literature,Volume I. Enugu: Fourth Dimension, 1980.

Clark, J.P. A Decade of Tongues. London: Longman, 198I. Constitution of the Federal Republic of Nigeria. Lagos: Federal Government Press, 1999

Eliot, T.S. "Tradition and Individual Talent," Oxford Anthology to English Literature, Volume II. Ed. Frank Kermode. NewYork: Oxford University Press, 1980.

Emenyonu, Ernest N. Studies on the Nigerian Novel. Ibadan: Heinemann, 1991.

Furniss, Graham. Poetry, Prose and Popular Culture in Hausa. London: $\quad$ Edinburgh University Press, 1999.

Kermode Frank, Hollander John, Bloom Harold and Price Martin (Ed.). The Oxford Anthology of English Literature, Volume I. London: Oxford University Press, 1980.

Nwoga, Donatus I. West African Verse. Harlow Essex: Longman, 1982.

Osundare Niyi. The Eye of the Earth. Ibadan: Heinemann, 1986.

\section{Press. 1983.}

Publishers), $\quad 1984$. 
Waiting Laughters. Lagos: Malthouse Press Limited, 1990.

Onions, C.T. The Oxford Dictionary of English Etymology. Oxford: Oxford University Press, 1966.

Pippin, Robert B. Idealism as Modernism, Hegelian Variations. United Kingdom: Cambridge_ University Press, 1997.

Soyinka, Wole. Idanre and other poems London: Methuen, I98I.

The Man Died. Ibadan: Spectrum, 1996.

Umeh, Okechukwu. Nigeria, We Hail Thee, Patriotic Poems. Onitsha: Benamax Publishers Limited, 1991.

Umeh, Patrick Okey. Poetry and Social Reality: The Nigerian Experience. Onitsha: Benamax Publishers Limited, 1991. Vansina, Jan. Oral Tradition, A Study in Historical Methodology. Chicago: Auden Publishing Company, 1960.

Websters New International Dictionary of the English Language. Springfield: $G$ and C Merriam Company, $2^{\text {nd }}$ Edition, Unabridged, 1937. 